har lest den foreliggende boken, vil være i tvil om at dette er høyst ufortjent.

Forfatterne er en britisk nevrolog, Christopher Hawkes, og en amerikansk luktforsker, Richard Doty. Sistnevnte er opphavsmannen bak den første standardiserte lukttesten i utbredt klinisk bruk, og er forfatter av over 300 artikler og flere bøker, de fleste innen lukt- og smaksforskning. Alt dette er destillert ned til denne lille boken på snaut 250 sider.

Resultatet er en liten perle av akademisk leseglede. I fem kapitler gjennomgår forfatterne luktesansens anatomi og fysiologi, klinisk luktevaluering, ulike forstyrrelser av luktesansen, forskjellige nevrodegenerative lidelser som affiserer luktesansen, og utredning og behandling av luktlidelser. Alle kapitlene er rikt illustrert i svart-hvitt, og de avsluttes med korte oppsummeringer etterfulgt av fyldige referanselister. Det avsluttende registeret er utfyllende og godt. På gammeldags manér er alle fargeillustrasjonene samlet for seg midt $i$.

Innledningskapitlet er en pedagogisk «tour de force». På mindre enn 50 små sider presenterer forfatterne en oppdatert oversikt over de anatomiske og fysiologiske aspektene av luktesansen - inklusive den grunnleggende luktforskningen som førte frem til Richard Axel og Linda Bucks nobelpris i medisin i 2004. For undertegnede, som ikke skjønte stort av Richard Axels foredrag under utdelingen av Kavli-prisen i Oslo i 2010, føles det å lese det første kapitlet som en intellektuell oppreisning: Jo, det er faktisk mulig å forstå dette likevel!

På samme kortfattede, instruktive måte gjennomgår forfatterne luktesansens betydning ved Parkinsons sykdom, Alzheimers sykdom og en lang rekke andre nevrodegenerative lidelser. De av oss som nøyer oss med å evaluere luktesansen ved hjelp av simpel gjenkjenning av kaffe og kamfer («Kan du lukte dette? Hva lukter det?»), får vårt pass påskrevet: Det er som å evaluere synsevnen ved å veive en lommelykt foran pasientens øyne og spørre: «Ser du lyset? Hvilken farge har det?»

Teksten er spekket med spennende luktfakta de færreste kjenner til fra før. Visste du at kvinner, som gruppe, har bedre luktesans enn menn? At mennesker som ikke kan lukte trimethylamin, har større tendens til å spise fisk? At den korteste veien fra en sansning til hippocampus, målt $i$ antall synapser, går via luktesansen? At cerebellum kan aktiveres av luktstimuli?

Boken er en døråpner til det usynlige universet av lukt som ligger, bokstavelig talt, rett foran nesen på oss. Jeg anbefaler den for alle kolleger som driver, eller burde drive, vurdering av luktesans i sitt kliniske virke.

\section{Godt ment, men mangelfullt}

Richard Colgan Advice to the young physician

On the art of medicine. 145 s, ill. New York, NY: Springer, 2010. Pris USD 35 ISBN 978-1-4419-1033-2

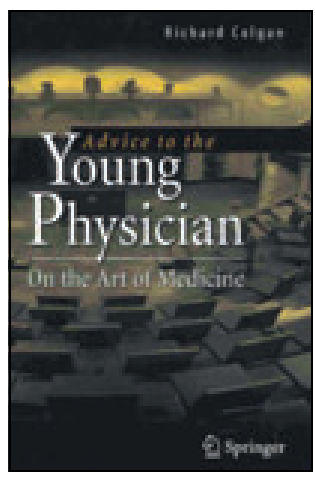

Dette er en lettlest, liten bok, som først og fremst handler om hva det vil si å være en god lege. Forfatteren er mangeårig allmennlege og førsteamanuensis ved University of Maryland School of Medicine. Boken har han skrevet for å hjelpe den unge legen til å mestre overgangen fra tekniker til helbreder. Dette skal oppnås, ifølge Colgan, ved å lære av dem som har gått opp veien før oss. I tråd med intensjonen bruker han drøyt halve boken på å fortelle om store leger fra oldtiden til moderne tid. Hippokrates, sir William Osler (1849-1919) og en av grunnleggerne av bioetikken, Edmund D. Pellegrino (f. 1920), vies størst plass. Men forfatteren inkluderer også Paul Farmer (f. 1951), infeksjonsmedisiner og antropolog, som i likhet med Pellegrino ser på kommersialiseringen av medisinen som et av de store menneskerettsproblemene i vår tid. Boken inneholder også mange anekdoter, eller kliniske perler, som forfatteren kaller det.

Siste del handler om mer praktiske og etiske råd til den unge legen, og kapitlene har titler som Survival tips to the young physician (med undertitler som What your defense attorney wants you to know).

I denne delen finner han også plass til The Twenty-Five Rules of Considerate Conduct.

Jeg har stor sans for forfatterens intensjon, og jeg liker også at han tør bruke ord som kall. Han ønsker å formidle hva legekunst er, og at medisinen er et etisk og humanistisk prosjekt. I forordet skriver han også at han vet hvem han skriver til, og det er til idealisten som strever for å bli en god lege, en komplett lege. Her ligger også noe av problemet; han bruker veldig store ord. Det er nok lett å falle av lasset hvis man ikke kjøper den hyppige insisteringen på at det å være lege er å være en helbreder.

Selv om målet er høyverdig, er metoden mer mangelfull. Boken er svært tilbakeskuende, og forfatteren berører ikke mer vitenskapsteoretiske aspekter. Han drøfter ikke hvordan helse og sykdom forstås, eller hva diagnoser er. Viktige utfordringer som medikalisering eller grenser for medisinens inngripen i menneskers liv, drøfter han heller ikke, ei heller ufordrende fenomener som medisinsk uforklarte plager og symptomer.
Jeg kan anbefale boken til de som ønsker en lettlest bok om medisinens «grand old men», og en påminnelse om viktige etiske prinsipper og kjøreregler. Men den som søker inspirasjon for å forstå legens og medisinens rolle i en kompleks virkelighet, bør søke annetsteds.

\section{Torgeir Gilje Lid}

Allmennmedisinsk forskningsenhet Uni helse

\section{Imponerende om syk lege}

Lars Saabye Christensen

Bernhard Hvals forsnakkelser

588 s. Oslo: Cappelen Damm, 2010.

Pris NOK 399

ISBN 978-82-02-33049-1

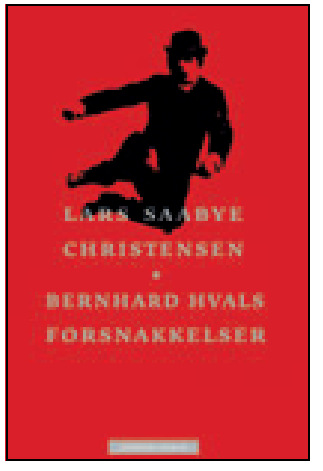

Når Lars Saabye Christensen (f. 1953) kommer med ny roman, er det alltid en begivenhet. Bernard Hvals forsnakkelser er da også en god bok. Det spesielt interessante er at fortellerstemmen ikke bare tilhører en

lege, men en syk lege. Bernard Hval har Tourettes syndrom. Både tvangstankene og de stadige, verbale ticsene som følger med sykdommen, preger ikke bare ordbruken i det som skal være hans livserindringer. De har også hatt sitt å si for hovedpersonens syn på livet. Bernhard Hval presenterer seg selv som «kantete», en av disse som ikke passer helt inn hvor enn han befinner seg. Alt ligger først til rette for at han skal bli lege på kirurgen B på Rikshospitalet, men han ender til slutt opp på rettsmedisinsk institutt. Der er det bare de døde som hører hans forsnakkelser.

En av styrkene til romanen er nettopp fortellerstemmen. Den gir med sine verbale krumspring historien et utrolig driv. I begynnelsen irriterte riktignok den gammeldagse språkbruken meg og fikk meg til å høre oppleserstemmen fra de gamle filmavisene $i$ hodet mens jeg leste. Men litt etter litt glemte jeg det. Jeg fikk i stedet en godhet for fortelleren Bernhard Hval og med det et helt annet fokus: Jeg satt til stadighet og engstet meg for at han skulle forsnakke seg.

Bernhard Hval prøver og feiler som medisinsk kliniker, og beskrivelser fra Rikshospitalet i mellomkrigstiden spiller en viktig rolle. Som lege selv synes jeg ofte forfattere som står utenfor helsevesenet, har en tendens til å henge seg opp i helt andre ting enn hva helsepersonell ville gjort. Saabye Christensen gjør ikke denne feilen. 
Både Bernhard Hvals medisinske eskapader og hans medisinske forståelse for ting er ikke mindre enn fantastisk godt gjengitt. Og legger man til det historiske aspektet ved teksten, kan jeg ikke si noe annet enn at boken er imponerende.

Lars Saabye Christensen beviser med Bernhard Hvals forsnakkelser at han er en forfatter med like mye medisinhistorisk innsikt som innlevelsesevne. Det er få norske forfattere som har en stødigere fortellerstemme.

\section{Christer Mjåset}

Nevrokirurgisk avdeling

Oslo universitetssykehus, Ullevål

\section{Hjertestarter med drapsvirus}

Anne Holt, Even Holt

Flimmer

432 s. Oslo: Piratforlaget, 2010. Pris NOK 379 ISBN 978-82-8143-262-8

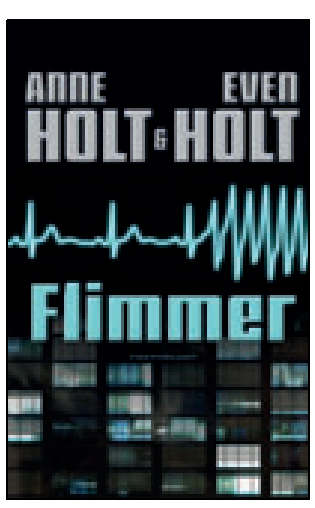

Anne Holt (f. 1958)

er en dreven krimforfatter. Hun har utgitt en rekke bøker av vekslende kvalitet. Fellesnevneren har vært aktuelle og snedige plott, mens språk og personskildringer ofte har vært flate og klisjépreget. I Flimmer har hun fått med seg broren, Even (f. 1963), som medforfatter. Han er kardiolog ved Bærum sykehus og blir behørig presentert på omslaget. Til og med årstallet for doktorgraden er med. Med broren på laget har Anne Holt forsterket den biten hun er god på selv: plottet. Hadde hun rekruttert en tredjemann med tilsvarende skjønnlitterær kompetanse, kunne dette blitt bra. Men dessverre, Flimmer er blitt en typisk Anne Holt-roman. Plottet er troverdig, personene ikke.

Handlingen utspiller seg på GRUS, Grini universitetssykehus, en hybrid av Rikshospitalet og Bærum sykehus. Her er hovedpersonen, den internasjonalt berømte kardiologen Sara Zuckerman, seksjonsoverlege. Bakgrunnen for at hun har havnet her, er selsomt konstruert.

For Sara Zuckerman tilhører toppsjiktet, hun har amerikansk statsborgerskap, er eksentrisk, arrogant og lynende begavet. $\mathrm{Og}$ - som navnet indikerer - hun er jødisk og eksotisk. «En stjerne var hun, en megastjerne, på en himmel større enn den over Norge, og Bærum ...». Nå, ja. Prosaen er i hvert fall umiskjennelig.

Boken starter med at Sara Zuckerman opererer inn en hjertestarter på sin tidligere elsker og kollega, professor emeritus Erik Berntsen. To dager senere får han hjertestans og faller død om. Noen dager senere skjer det samme med en annen tilfeldig pasient. Og en tredje unngår så vidt samme skjebne. Hjertestarteren som skulle redde liv, har fått en omvendt funksjon. Noen har plantet et virus i den implanterbare defibrillatoren (ICD) og gjort den til en drapsmaskin. Hvem er skurken? Vel. Den geniale nerden som laget programmet, er død, men etterlot seg en minnepinne. Hvem har fått tak i den, og hvorfor dukker viruset opp først mange år senere? Hvorfor i Norge? Og hvorfor i Bærum? Jo da. Plottet er spenstig.

Defibrillatoren er produsert av Mercury Medicals, et USA-basert, verdensledende firma. Selskapet er bunnsolid. Den norske stat kontrollerer $33 \%$ av eierandelene etter å ha investert svimlende 500 milliarder av oljefondet. Toppsjef og gründer av Mercury er et maskinmenneske med «tyrenakke» og «total mangel på empati». For å fjerne enhver tvil om psykopatdiagnosen er han i tillegg utstyrt med det tyskklingende navnet Otto Schultz - og alle assosiasjoner det måtte vekke. Slik punkteres spenningen, allerede før leseren er skikkelig i gang. Det hamres inn: Otto Schultz er skurken over alle skurker, uten en eneste formildende egenskap.

Sara Zuckermans våpendrager $\mathrm{i}$ kampen for å avsløre hvem som står bak de virusinfiserte defibrillatorene, er assistentlegen Ola Farmen. Som Even Holt er Ola Farmen lege og sivilingeniør fra NTH. Der stopper muligens likhetene. For Ola Farmen er en intelligent rotekopp som tøyer alle regler, i kronisk mangel på penger og søvn, fem unger med navn som begynner på $\mathrm{T}$, psykiaterkone og hus og bil i et salig kaos.

Det kryr av personer. I de første kapitlene introduserer forfatterne like mange karakterer som i en Tolstoj-roman. Det lesses på med privatliv og familiebeskrivelser, pratsomt og forutsigbart, side opp og side ned. Figurene er sjablongmessig konstruert. For endimensjonale til å bli interessante. For karikerte til å bli troverdige. Spesielt rammer dette hovedpersonen, Sara Zuckerman. Som verdensstjerne og baconspisende, bannende jøde fra Tromsø er hun uten enhver troverdighet.

Hvem vil ha glede av boken? Anne Holts trofaste lesere vil ikke bli skuffet (eller overrasket). De medisinsk interesserte kan få en grundig innføring i funksjon og implantasjon av defibrillatorer, ettersom første kapittel er skrevet nærmest som bruksanvisning og håndbok. For lesere med sans for et spenstig krimplott kan boken være bingo på en kjedelig flytur. Men det forutsetter overbærenhet med traurig brukskunstprosa og magaplaskende karakterer.

May Brit Lund

Lungeavdelingen

Oslo universitetssykehus, Rikshospitalet

\section{Roman om menneskets litenhet}

David Lodge

Deaf sentence: a novel

320 s. London: Penguin, 2009. Pris GBP 9 ISBN 9780141035703

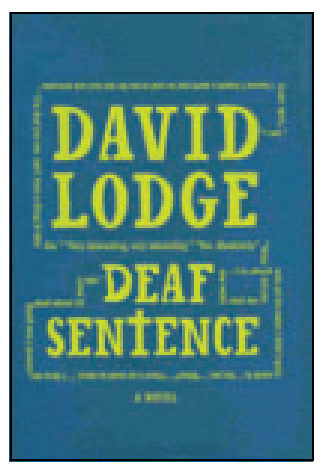

I dedikasjonen som han tilegner oversetterne av sine romaner, innrømmer David Lodge (f. 1935) at han er klar over at allerede fra tittelen av byr denne romanen på problemer. Deretter siterer han en Oxford-ordbok

som angir sju forskjellige betydninger av ordet «sentence», før vi blir konfrontert med professor Desmond Bates, en engelsk lingvist som har gått av med tidlig pensjon. Desmond Bates er svært hemmet av nedsatt hørsel, han er på det nærmeste døv. Dessuten er han sønn av en nå 89 år gammel tidligere dansemusiker som er enkemann og ikke lenger i stand til å klare seg selv. Men det vil ikke faren medgi. Og dermed er vi midt oppe i geriatriske problemstillinger med begynnende demens, vrangforestillinger, f.eks. om skattevesenets egentlig rolle, og økende prostatisme. Dette møter Desmond Bates med full tyngde. På den annen side har Desmond Bates voksne barn med problemer. Han står med sine egne vansker midt mellom to generasjoner. Samtidig kommer vi som lesere inn i den døves verden. Lodge lar oss oppleve de uforståelige samtalene med bisarre svar på hva man trodde var spørsmålet, forsøkene på å holde en daglig konversasjon gående, vel vitende om at man ikke har en anelse om hva motparten snakker om. I neste avsnitt gir han oss fasiten: hva samtalen egentlig handlet om, ved å flytte seg fra første til tredje person.

Den tunghørte professoren tar i bruk tekniske hjelpemidler, og de er til hjelp, men bare delvis. Dessuten må man alltid ha riktige batterier for hånden. $\mathrm{Og}$ apparatene er små og ikke så enkle å håndtere. Legg så til at hovedpersonen er gift med en noe yngre kvinne som har skapt seg en karriere med moteforretning. Det er duket for problemer og misforståelser. David Lodge kjenner dem alle og skriver med varme og medfølelse. Professoren savner sitt arbeid, men bare av og til. Da han blir spurt om å være veileder for en sjarmerende, ung kvinne, som frister ham slike enkelte akademikere ofte har ønsket å bli fristet, slår hans moralske integritet til, og han motstår fristelsen.

$\AA$ være blind er tragisk, men å være døv er komisk, forsikrer Lodge oss, og viser oss svært mange komiske hendelser. Beskrivelsen av kurset for å lese på munnen er 